\title{
A FELHÖTECHNOLÓGIA: SZOLGÁLTATÁSI SZINTEK, ADATVÉDELEM, SZERZŐI JOGI KÉRDÉSEK
}

\author{
Tószegi ZsuZsANNA
}

ELTE BTK KITI, címzetes egyetemi docens

\begin{abstract}
ABSZTRAKT
A világban keletkező óriási adattömegek, a „big data” kezelése (tárolása, feldolgozása, hozzáférhetővé tétele stb.) a ma rendelkezésre álló technológiai megoldások határát feszegeti. Becslések szerint a tárolt adatmennyiség nagyjából kétévenként megduplázódik. A big data nemcsak menynyiségi szempontból jelent óriási kihívást - legalább ekkora gondot okoz az adatok változatossága, illetve az adatok keletkezésének és rendelkezésre bocsátásának iszonyatos sebessége. Az adatrobbanás szükségszerủen hívott életre olyan új technológiákat, mint az adatbányászat és a felhőtechnológia. A mai hálózati aktivitást nem lehetne biztosítani a régi kliens-szerver architektúrákkal: nélkülözhetetlenné váltak a felhőtechnológiára épülő szolgáltatások, amelyek óriási kihívást jelentenek technikai, pénzügyi, adatvédelmi, szerzői jogi stb. szempontból egyaránt.
\end{abstract}

\section{A big data jelenség}

A vezető tudományos orgánumok néhány éve kezdtek foglalkozni az adatrobbanás, a big data jelenséggel. A világban keletkező óriási adattömeg kezelése (tárolása, feldolgozása, hozzáférhetővé tétele stb.) a ma rendelkezésre álló technológiai megoldások határát feszegeti. Becslések szerint a tárolt adatmennyiség nagyjából kétévenként megduplázódik.

Vannak különösen nagy adathalmazt előállító tudományterületek, mint például a meteorológia, a környezetvédelem, a genetika, a szeizmográfia. Folyamatosan áramlik a földi megfigyelőközpontokba a hatalmas adatmennyiség a csillagászati teleszkópokról, a Föld körül keringő múholdakról. ${ }^{1}$

A CERN nagy hadronütköztetőjéhez viszonyítva egy-egy magánember lényegesen kisebb adathalmazt termel és fogyaszt, de ha összeadjuk a közösségi médiumok használói által generált forgalmat, már óriási mennyiséget kapunk. 2014-ben több mint 2 milliárd ember használt digitális kamerát, amelyekről a képek/videók nagy részét feltöltötték a közösségi oldalakra. 2016. január 10-én a Facebooknak 1,440 milliárd tagja volt, közülük 936 milliónyian napi rendszerességgel használták a közösségi oldalt, a Twitteren keresztül pedig napi 500 millió hír ér el a 316 millió felhasználóhoz. ${ }^{2}$

Az elektronikai és infokommunikációs ipar helyzetének elemzésére szakosodott, piacvezető IDC cég rendszeresen közzéteszi a digitális világ helyzetét bemutató, elemző tanulmányait. 2014 áprilisában készült a digitális eszközök 2014. évi adatait és a jelenlegi trendek alapján 2020-ra megjósolható növekedését bemutató jelentés, amelynek összefoglaló ábráját két részre bontva mutatjuk be az alábbiakban. 


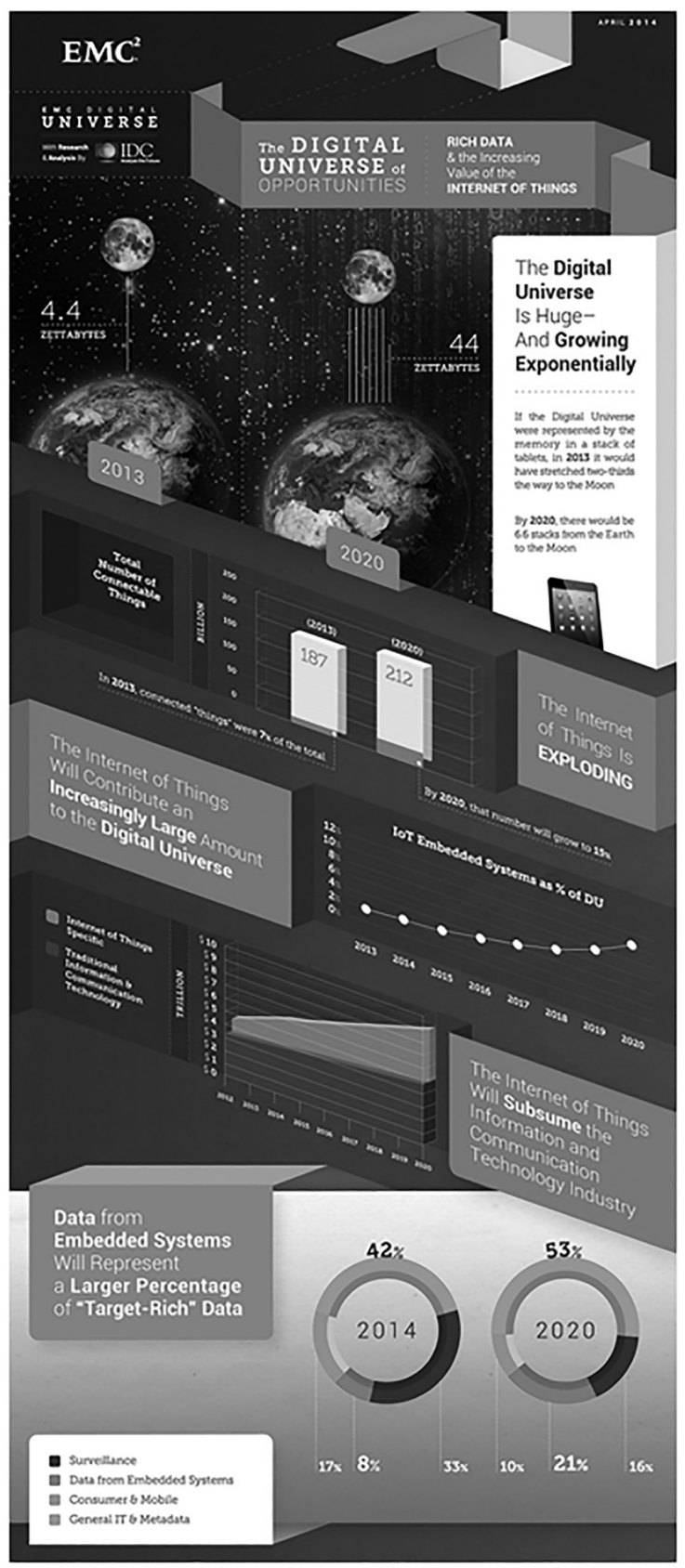

1. ábra: $A$ dolgok internete ${ }^{3}$

Az eredeti infografika felső része (1. ábra) a „dolgok internete”, vagyis az internetre kötött különféle eszközök 2013. évi, illetve a 2020-ban várható mennyiségét érzékelteti. 
Az IDC adatai szerint 2013-ban 4,4 zetabájt (10 $10^{21}$ hatványon) adatot tároltak a számítógépes háttértárakon. Az exponenciálisan növekvő adatmennyiség 2020-ra előre láthatólag megtízszereződik.

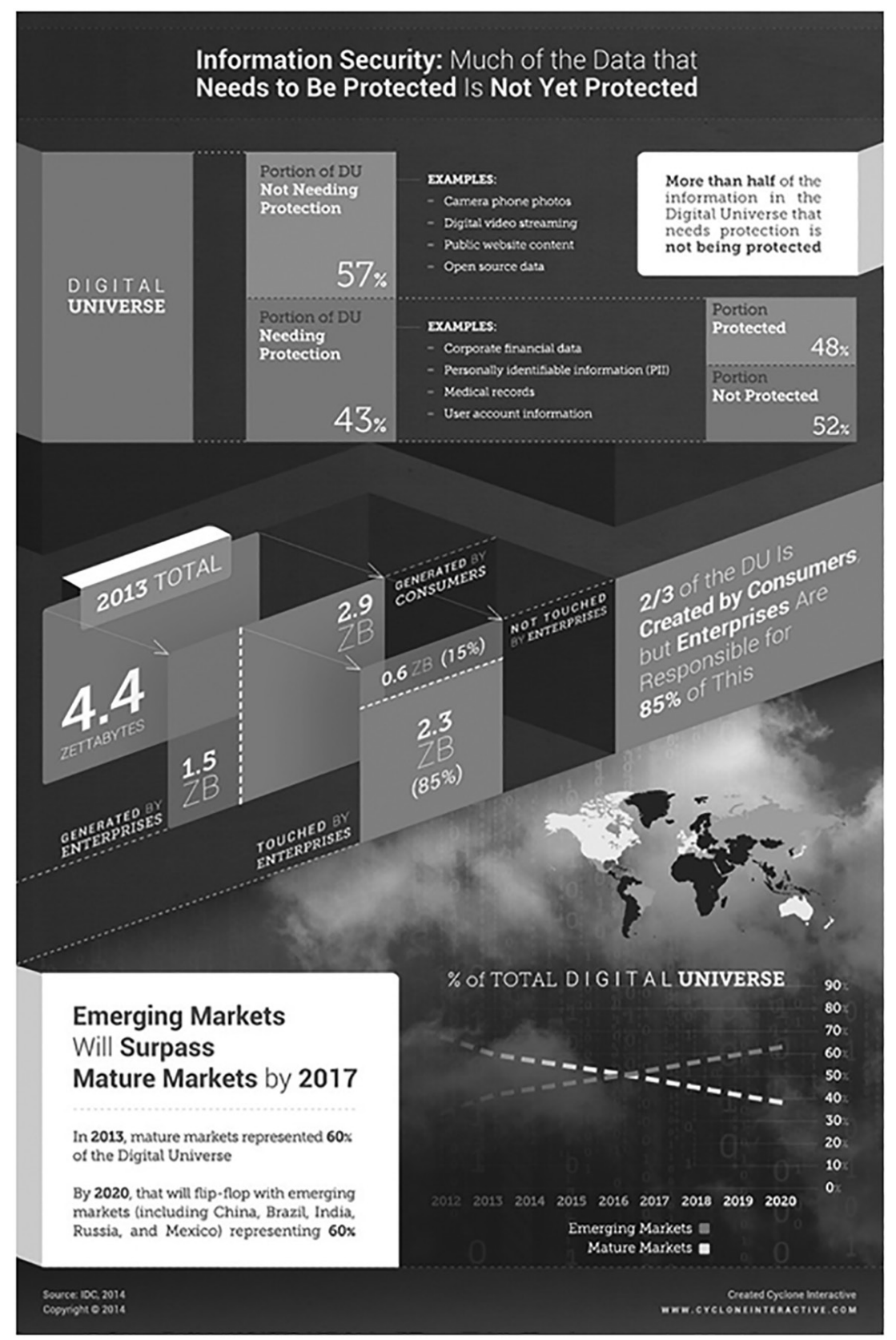

2. ábra: A digitális univerzum mérete és várható növekedése ${ }^{4}$ 


\section{TÓSZEgI ZsuZSANNA}

Ahogy az IDC infografikájának alsó felén (2. ábra) látható, az egyes IT ágazatok megoszlása jelentősen módosul: 42\%-ról 52\%-ra nő az IT eszközök és a metaadatok aránya, 8\%-ról 21\%-ra növekszik a beágyazott rendszerek adattömege - viszont a felére, 33\%ról 16\%-ra esik vissza a megfigyelőrendszerekben tárolt információ, illetőleg 17\%-ról 10\%-ra csökken a kereskedelem és a mobil eszközök által generált adatmennyiség.

Az ENSZ Európai Gazdasági Bizottsága (United Nations Economic Commission for Europe = UNECE) 2013-ban létrehozott egy munkacsoportot a big data jelenség tanulmányozására. A bizottsághoz a statisztikai hivatalokból érkeznek az adatok. Az exponenciális növekedés az általuk közölt ábrán is jól látható - a növekedés 2016 körül áll az igazán meredek pályára. ${ }^{5}$

A big data nemcsak mennyiségi szempontból jelent óriási kihívást - legalább ekkora gondot okoz az adatok változatossága, illetve az adatok keletkezésének és rendelkezésre bocsátásának iszonyatos sebessége. Az adatrobbanás szükségszerủen hívott életre olyan új technológiákat, mint az adatbányászat és a felhőtechnológia.

A technológiai paradigmaváltás nemcsak az eszközökre fejti ki hatását. A rendelkezésre álló, mind pontosabb, valós idejű, jól követhető és elemezhető adattömegnek köszönhetôen a gazdaságban megváltozik a döntéshozatal mikéntje: a tapasztalatokra, a megérzésre épülő, intuitív vezetői attitűd erőteljesen visszaszorul; a helyét átveszi az adatelemzésre alapozott, racionális, preventív döntési mechanizmus. ${ }^{6}$ Ez utóbbit nagyban segíti az adatbányászat (data mining), amely az eddig soha nem látott adatsorok elemzésével korábban elképzelhetetlen információkat szolgáltat a döntéshozók számára.

A technológia hatása az Én-központú hálózatok alakulására

A hálózatba kötött világ nem csupán a technológiai eszközök fejlesztésére, elterjedésére gyakorol alapvető befolyást: legalább ennyire hat a világhálóra folyamatosan kapcsolódó emberekre. A hálózatkutatás eredményeit tanulmányozva sokat megtudhatunk arról, hogyan viszonyul a ma embere a társaihoz. Míg korábban a társadalmi függóség, illetve az érzelmi dimenziók határozták meg az emberek kapcsolati hálóját, ma embertársaink nagy részére úgy tekintünk, mint potenciális erőforrásokra, akikkel sajátos kognitív kapcsolatba kerülünk.

A kutatások azt bizonyítják, az egyes korosztályokra jellemző, miként befolyásolják a technikai eszközök a kapcsolati hálójuk alakulását. A középiskolások például rendkívül intenzíven, ugyanakkor adaptívan használják az egymás közti kapcsolattartásra a mobil kommunikációs eszközöket. A tanár-diák viszony kommunikációs eszköze elsősorban az e-mail lett.

A felnőttek esetén a kialakult személyiség erősen befolyásolja a hálózati eszközök használatát. Csak két példa: az extrovertált férfiak előszeretettel használják szórakozásra az internetet; az introvertált nők nem kedvelik a kérdéseket feltevő oldalakat. A személyiség dimenziói és a hálózatok alakulása között a megfelelés nem egydimenziós, hanem sok összetevős, finom beállítódás. ${ }^{7}$ 
A FELHŐTECHNOLÓGIA: SZOLGÁLTATÁSI SZINTEK, ADATVÉDELEM, SZERZŐI JOGI KÉRDÉSEK

\section{A felhötechnológia}

A mai hálózati aktivitást nem lehetne biztosítani a régi kliens-szerver architektúrákkal: nélkülözhetetlenné váltak a felhőtechnológiára épülő szolgáltatások, amelyek óriási kihívást jelentenek technikai, pénzügyi, adatvédelmi, szerzői jogi stb. szempontból egyaránt.

A felhőalapú számítástechnika gondolata nem új keletű: a mesterséges intelligencia atyjaként ismert John McCarthy 1960-ban fejtette ki korszakalkotó álláspontját: az informatikai szolgáltatásoknak ugyanolyan közmű-jellegűen kellene működniük, mint az áram- vagy a vízszolgáltatásnak. Az ARPANET fejlesztési vezetője, J. C. R. Licklider 1969-ben írta le elképzeléseit arról az intergalaktikus számítógépes hálózatról, amely a Föld valamennyi lakóját összekapcsolná bárhol, bármikor hozzáférhető programok és adatok használata segítségével. ${ }^{8}$

A számítási felhő definícióját így határozza meg az Európai Bizottság közleménye: adatok interneten keresztül elérhető, távoli számítógépeken történő tárolása, feldolgozása és felhasználása. A felhasználóknak nincs szükségük jelentős informatikai beruházásokra, mert a számítási felhőben gyakorlatilag korlátlan kapacitáshoz juthatnak, és az ott tárolt adataikat bármely internet-hozzáféréssel rendelkező helyről és eszközről elérhetik. „Míg a világháló az információkat, addig a számitási felhő a számitási teljesitményt teszi mindenhol és mindenki számára elérhetövé."9

Az amerikai szabványügyi és technológiai hivatal (National Institute of Standards and Technology - NIST) szerint a felhőszolgáltatás jellemzői ${ }^{10}$ :

- Az eröforrások közös használata: több felhasználó ugyanazon a hardver-, szoftver- és hálózati eszközökön osztozik.

- Rugalmasan és gyorsan bövithetó, szinte végtelen teljesitóképesség: az igényelhető kapacitás majdhogynem korlátlan. A fogyasztás mérhetô és követhető, a rendszer teljesítőképessége dinamikusan növelhető vagy csökkenthető.

- Magas fokú biz̨tonság: a szolgáltatást professzionális eszközökkel védik a támadások ellen.

- Széles sávú hálózati elérés: egyre több helyen rendelkezésre áll a kellő sávszélesség.

- Kedvezó ár/érték arány: a szolgáltatás olcsóbb, mintha saját eszközparkot kellene beszerezni és üzemeltetni.

A felhőszolgáltatás ismert modelljei:

- Infrastruktúra szolgáltatás (Infrastructure as a Service - IaaS): a szolgáltató virtuális szervert, tárhelyet, hálózati kapcsolatot, számítási kapacitást nyújt, de a rendszert és az alkalmazásokat az ügyfél üzemelteti.

- Platformszolgáltatás (Platform as a Service - PaaS): az alkalmazások üzemeltetéséhez szükséges környezetet (operációs rendszert, adatbázis-kezelőt stb.) a szolgáltató biztosítja, de az adatokat a megrendelő kezeli.

- Szoftverszolgáltatás (Software as a Service - SaaS): a szolgáltató biztosítja a teljes hardverés szoftverparkot; a fogyasztó csak a felkínált szolgáltatások közül tud választani. 
A hozzáférhetőség alapján négy nagy csoportot különböztetünk meg:

- Publikus felhő - a szolgáltató ugyanazt az eszközállományt (szerver, tárhely, hálózat, szoftverek, alkalmazások) bocsátja ügyfelei rendelkezésére.

- Privát felhő - saját vagy bérelt erőforrásokon lehet építeni, az üzemeltetésről a privát felhő tulajdonosának kell gondoskodnia.

- Hibrid felhő - a privát és a publikus felhő kombinációja, amely alapjaiban saját felhőt jelent, de átmeneti teljesítményigény esetén lehetővé teszi az erőforrásigény kiegészítését a publikus szolgáltató által kínált kapacitásokkal.

- Közösségi felhő - meghatározott feltételekkel több szervezet/személy veheti igénybe a szolgáltatást.

A felhöszolgáltatások szerzooi jogi aspektusai

A felhőben való felhasználások szerzői jogi minősítésére még nem alakult ki konszenzusos vélemény. ${ }^{11}$ A felhôszolgáltatás három tipikus szereplője:

- a szolgáltatást nyújtó,

- a szolgáltatást igénybe vevő, valamint

- a hozzáférés-szolgáltató.

A szerzői jogi védelem alatt álló múvek feltöltésében, a tartalom kezelésében, illetve hozzáférhetôvé tételében mindhárom szereplő szerepe és felelőssége eltérő.

A tartalomkezelés szempontjából a csakis tárhelyet szolgáltatók nem végeznek a szerzői jogi törvény hatálya alá tartozó cselekményt, mivel nem kezelik a feltöltött tartalmat. Azok a szolgáltatók, amelyek kapacitásaik jobb kihasználása érdekében tartalomelemzést és -menedzselést folytatnak - például a sokak által feltöltött, azonos tartalmakból csak egy-egy példányt tárolnak, és ezt szolgáltatják - szerzői jogi szempontból többszörözést, gyűjteménybe foglalást stb. végeznek, méghozzá üzleti haszonszerzési céllal. Hiába magánszemélyek a feltöltők, a szolgáltatók tevékenysége nem minősíthető szabad felhasználásnak: engedélyhez kötött és díjfizetési kötelezettséggel jár. ${ }^{12}$

A privát felhőben érvényesülhet a szabad felhasználás - feltéve, hogy a feltöltő magánszemély, és csakis az általa megjelölt, dedikált személyek (családtagok, barátok) férhetnek hozzá a tartalomhoz. A bárki által hozzáférhető publikus felhőben azonban akkor is engedély- és díjköteles cselekmény a feltöltés, ha a feltöltő magánszemély - kivéve a közkincsbe tartozó műveket.

A szerzői jogi szabályozás egyik fontos alapvetése a territorialitás elve. „A szellemi alkotások jogára a nemzetközi magánjog terén főszabályként a területhez kötöttség (a territorialitás elve) az irányadó, azaz a szerzői jog és az iparjogvédelmi jogosultság csak annak az országnak a területén áll fenn, ahol az létrejött." ${ }^{13}$ Az egyik legbonyolultabb kérdés: miként lehet a felhőszolgáltatások esetében érvényesíteni a szerzői jog territoriális jellegét.

\section{A felhötechnológia elónyei és hátrányai}

Vitathatatlan előnyei miatt egyre több magán- és üzleti szolgáltatás „költözil” a felhőbe. Az előnyök közül a legfontosabb a költségcsökkentés. Könnyű belátni, mennyivel gazdaságosabb, ha valaki a felhőszolgáltatást veszi igénybe, és nem saját infrastrukturális erőforráso- 
kat múködtet. ${ }^{14}$ További előny a folyamatos szoftver és hardver megújítás, amelynek eredményeként a felhőben az ügyfél a legkorszerúbb IT környezetben végezheti tevékenységét.

A hátrányok közül az adatbiztonságot szokták kiemelni. A szolgáltatást igénybe vevők a hardver- és szoftvereszközök saját mûködtetésével együtt az adataik fölötti totális ellenőrzésről is lemondanak. További akadályozó tényező a sávszélesség nem mindenkor és nem mindenhol elegendő volta. A minőségi szolgáltatást akadályozza, ha a kicsi sávszélesség miatt meg-megszakad a kapcsolat.

Jean-Philippe Accart egy további hátrányra hívja föl a figyelmet a felhőben tárolt e-könyvek megvásárlása kapcsán. A szerző a słabadságjogok elleni támadásnak minősíti azt, hogy a vásárló a felhőbôl kizárólag az anonimitása feláldozásával tud megvenni egy e-könyvet - szemben a nyomtatott könyvek könyvesbolti beszerzésével, ahol készpénzes vásárlás esetén nem kell a vevőnek fölfednie kilétét. ${ }^{15}$

A hátrányok közé tartozik továbbá tradicionális jogaink sérülése. Amíg a nyomtatott múpéldányok megvásárlásával bizonyos korlátozott jogaink is keletkeznek: kölcsönadhatjuk, odaajándékozhatjuk, de el is adhatjuk a birtokunkban lévő példányt - mindez a cselekmény az e-könyvekkel kapcsolatosan tiltott. Az e-könyvek esetében ugyanis nem példányvásárlás történik, csupán olvasási licencet szerzünk meg. A szolgáltató emellett az olvasási lehetôségeket is korlátozhatja, amikor megszabja, milyen formátumban, milyen eszközön olvashatjuk el a könyvet.

\section{Könyvtárak a felhöben}

A már idézett cikkében Sharon Q. Yang rámutat, hogy 2011 óta egyre több szállító költözteti integrált könyvtári rendszerét a felhőbe. Ezzel nemcsak az üzemeltetés módja változik: a kliens-szerver architektúrára épülő, hagyományos rendszerekhez képest az új generációs integrált rendszerek számos előnyös tulajdonsággal bírnak. Néhány példa: „egyablakos” keresés az egységesített indexekben, sok szempontú keresési lehetőségek lehetővé tétele, direkt összeköttetés a közösségi média rendszerekkel.

Nagy előny, hogy a felhasználók a felhőszolgáltatásokat nem kliens programmal, hanem böngészőn keresztül érik el, így a szállító megszabadul a költséges telepítéstől és a folyamatos karbantartástól.

Az elektronikus licenc-menedzsment program kezeli és nyilvántartja a hozzáférési jogosultságokat, az esetleges díjfizetési kötelezettségeket stb. A felhőből szolgáltatott integrált könyvtári rendszer további előnye a könnyű adatcsere: nincs tovább szükség a külön-külön telepített szoftverekre, sokkal könnyebb megoldani a folyamatos adatcserét, a rekordok átadását.

A felhőtechnológia arra készteti a szállítókat és a könyvtárakat egyaránt, hogy új nézőpontból vizsgálják felül működésüket, szolgáltatásaikat. A klasszikus integrált könyvtári rendszerek korszaka leáldozóban van, de kár lenne ezen sajnálkozni. Az innovatív, új generációs könyvtári rendszerek jó helyzetbe hozzák a könyvtárakat: megszűnik a véges tárolókapacitás, nem kell gondoskodniuk hozzáértő IT szakemberekről, lekerül róluk a szolgáltatások folyamatos felügyeletének terhe - ráadásul korszerū keresőrendszerek állnak rendelkezésükre és további új lehetőségek nyílnak meg előttük. ${ }^{16}$ 


\section{Irodalom}

${ }^{1}$ BŐGEL György: Az adatrobbanás mint közgazdasági jelenség. = Közgazdasági Szemle, 58. évf. 2011. október. 877-889. p.

${ }^{2}$ Facebook statistics directory. Forrás: http://www.socialbakers.com/statistics/facebook, http://[-] www.socialbakers.com/statistics/twitter [2016. január 10.]

${ }^{3}$ The Digital Universe of Opportunities. Visualize the digital universe: billions of everyday objects report and receive data with no human interaction. Who's responsible for protecting that data? Forrás: http:/ /www.emc.com/infographics/digital-universe-2014.htm [2016. január 10.]

${ }^{4}$ The Digital Universe of Opportunities. i. m.

${ }^{5}$ Background to UNECE's Big Data work. All Global Data in Zettabytes. Forrás: http://[-] www1.unece.org/stat/platform/display/msis/Big+Data [2016. január 10.]

${ }^{6}$ BÖGEL György: i. m.

${ }^{7}$ PLÉH Csaba: Az ént körülvevő hálózatok meghatározói: kognitív, evolúciós és szociálpszichológiai mozzanatok. In: Változó életformák, régi és új tanulási környezetek. Sorozatszerk. Bárdos Jenő, Kis-Tóth Lajos, Racsko Réka, Budapest, MTA Pedagógiai Tudományos Bizottság, 2013. 181-193. p.

${ }^{8}$ MOHAMED, Arif: A history of cloud computing. Forrás: http://www.computerweekly.com/[-] feature/A-history-of-cloud-computing [2016. január 8.]

${ }^{9}$ Európai Bizottság. A számítási felhőben rejlő potenciál felszabadítása Európában. MEMO. Brüsszel, 2012. szeptember 27. Forrás: http://europa.eu/rapid/press-release_MEMO-[-] 12-713_hu.htm [2016. január 8.]

${ }^{10}$ TÓSZEGI Zsuzsanna: A felhőalapú számítástechnika szerzői jogi kérdései. In: Korszerű könyvtár. Szakmai szerk. Dán Krisztina, Fehér Miklós, Budapest, Raabe Kiadó, 2015. 1-14. p.

${ }^{11}$ FALUDI Gábor - GRAD-GYENGE Anikó: A cloud computing-alapú szolgáltatások szerzői jogi megítéléséről. = Infokommunikáció és Jog, 9. évf. 50. sz. 2012. 105-108. p.

${ }^{12}$ FALUDI Gábor - GRAD-GYENGE Anikó: i. m.

${ }^{13}$ FORGÁCS Tünde: A szellemi tulajdon területét szabályozó nemzetközi szerződések a magyar jogban, különös tekintettel az e szerződéseket kihirdető nemzeti jogforrásokra és a soft law problematikára. $=$ Publicationes Universitatis Miskolciensis. Sectio Juridica et Politica, Tomus XXX/1. 2012. 271-289. p. Forrás: http://www.matarka.hu/koz/ISSN_0866-[-] 6032/tomus_30_1_2012/ISSN_0866-6032_tomus_30_1_2012_271-289.pdf [2016.január 10.]

${ }^{14}$ Q. YANG, Sharon: Move into the cloud, shall we? = Library Hi Tech News, No. 1. 2012. 4-7. p.

${ }^{15}$ ACCART, Jean-Philippe: Hot off the press: digital reading. = Library Hi Tech News, No. 7. 2012. 13-15. p.

${ }^{16}$ Q. YANG, Sharon: i. m.

Tószegi Zsuzsanna az 1990-es évektől óraadó az Eötvös Loránd Tudományegyetem informatikus könyvtáros szakán, illetve a doktori programban. 2006-2015 között főiskolai, majd egyetemi docens a Kaposvári Egyetem Pedagógiai Karán. 2015-től az ELTE BTK Könyvtár- és Információtudományi Intézetének címzetes egyetemi docense. 